\title{
Leucovorin Calcium
}

National Cancer Institute

\section{Source}

National Cancer Institute. Leucovorin Calcium. NCI Thesaurus. Code C607.

An active metabolite of folic acid (also called folinic acid and citrovorum factor), which does not require metabolism by dihydrofolate reductase, the molecular target of folate antagonist-type chemotherapeutic drugs. Leucovorin calcium counteracts the toxic effects of these medications, 'rescuing' the patient while permitting the antitumor activity of the folate antagonist. This agent also potentiates the effects of fluorouracil and its derivatives by stabilizing the binding of the drug's metabolite to its target enzyme, thus prolonging drug activity. ( $\mathrm{NCl04)}$ 